Eskişehir Osmangazi Üniversitesi IïBF Dergisi

Aralık 2020, C. 15, S. 3, 1119- 1134

Başvuru : 28.03.2019

Kabul : 06.05.2020

\title{
İşveren Markasının İşe Bağlılık Üzerindeki Etkisi: Bir Beyaz Eşya Firması Çalışanlarına Yönelik Uygulama
}

Nuray Girginer ${ }^{1}$

Aslı Çelik ${ }^{2}$

İşveren Markasının İşe Bağlılık Üzerine Etkisi: Bir Beyaz Eşya Firması Çalışanlarına Yönelik Bir Uygulama

Öz

$\mathrm{Bu}$ araştırmanın amacı işletmelerin işveren markası adı altında çalışanlarını elde tutmak ve potansiyel adayları işletmeye çekebilmek adına sundukları uygulamaların mevcut çalışanların işe bağlılıkları üzerine etkisi olup olmadığını belirlemektir. Araştırmanın verileri Eskişehir Organize Sanayi Bölgesi'nde faaliyetini sürdüren bir beyaz eşya firmasının 223 beyaz yaka çalışanından anket tekniği ile toplanmıştır. Açıklayıcı Faktör Analizi (AFA) sonucunda işe bağlılık ölçeği 3 temel faktör, işveren markası ölçeği 5 temel faktör altında toplanmıştır. İşveren markası uygulamalarının çalışanların işe bağlılıkları üzerine etkisini belirlemek amacıyla yapılan Regresyon Analizi sonucunda; işletmenin işveren markası uygulamalarının çalışanlarının işe bağlılıkları üzerinde pozitif yönde anlamlı bir etkisi olduğu ortaya çıkmıştır.

Anahtar Kelimeler: İşe bağlılık, İşveren markası, Açıklayıcı Faktör Analizi, Regresyon analizi
Effect on the Employment of Employer's Brand: An Application for White Goods Industrial Employees

Abstract

The purpose of this research is to determine whether the practices that they intend to pursue to keep employees under the employer brand name and attract potential candidates that they have an effect on the existing employees' commitment to work. The study's data were collected from 223 white collar employees of a white goods company in the Eskisehir Organized Industrial Zone by survey technique. As a result of the Explanatory Factor Analysis (EFA), the three main factors for work commitment scale and 5 main factors for employer brand scale extracted. As a result of the regression made to determine the effect of employer brand applications on employees' commitment to work; it has emerged that the employer's branding practices have a significant positive effect on employees' commitment to work.

Keywords: Work commitment, Employer brand, Exploratory factor analysis, Regression analysis

\section{Giriş}

Günden güne değişen pazar şartlarında işletmeler yüksek verimlilik ve rakiplerine karşı rekabet avantajı sağlayabilmek adına ürün veya hizmetlerinin diğerlerine göre farklı görünmesi için çalışmaktadırlar. Söz konusu farklılığı; maliyetleri düşürerek, yeni avantaj sağlayan yatırımlar yaparak, sipariş teslim sürelerini kısaltarak, kapasite esnekliğine ulaşarak, kalite standartlara uyarak, yeni ürün veya hizmetler sunarak yaratmaktadırlar.

Çalışanlar açısından bakıldığında; işletmeler imajını yükselterek nitelikli iş gücünü işletmelerine çekmeye çalışmaktadır. Mevcut çalışanların ise işletmeye bağlılıklarını arttırarak pazarda üstünlük sağlayabilecek iş çıktılarına ulaşmayı amaçlamaktadırlar. Nitelikli ve fark yaratan yeteneklerden yararlanmayı, çalışanlarını firmada tutmayı ve onların motivasyonunu yüksek tutarak verimliliklerini arttırmayı hedeflemektedirler. Bu kapsamda işletmeler dönem dönem çalışan bağlılıklarını ölçümleyerek, bağlılığı daha da artırabilecekleri çalışmalar yapmaktadır. Günümüzde bu çalışmalar işletmenin vizyonunu, değerlerini ve kültürünü hem çalışanlara hem de potansiyel çalışanlara yansıtabilmek adına işveren markası faaliyetleri adı altında yapılmaktadır. Bu faaliyet ve uygulamalar, çalışanların örgüte olan bağlılıklarını

${ }^{1}$ Prof. Dr., Eskişehir Osmangazi Üniversitesi iiBß İşletme Bölümü, ngirginer@gmail.com, Yazar ORCID bilgisi: 0000-00031228-5800

${ }^{2}$ Kıdemli İnsan Kaynakları Uzmanı, asli.celik@arcelik.com, Yazar ORCID bilgisi: 0000-0001-8135-7818 
arttırmakla birlikte dolaylı olarak iş tatminine ulaşmalarını da sağlamaktadır. Bilindiği gibi iş tatminine ulaşmış çalışanların işe bağlılığından söz etmek mümkündür. İşe bağlılık kavramı bu kapsamda; mevcut çalışanların işletmede tutundurulmasında önemli bir unsur haline gelmiştir. İşletmeler çalışanların işe bağlılıklarını sağlayabilmek adına çalışanların menfaatlerine yönelik uygulamalar sunmaktadır. Bu uygulamalar işe bağııık kadar önemli olan ve sürekli geliştirilmesi gereken işveren markası adı altında toplanmaktadır.

İşveren markası, marka olarak işvereni öne çıkartmayı, işvereni diğer işletmelerin önüne taşımanın yanında işletme içi uygulamalarda bir standardizasyon oluşturarak çalışanlara adil ve tarafsız yaklaşımlar sergilemeyi amaçlamaktadır. İşveren markası adı altındaki uygulamalardan;

Ücret ve yan haklar, yapılan iş ve çalışanın bulunduğu kademe kapsamında değişiklik gösterebilmekte ve eşdeğer bir kademede ya da görevde farklılık göstermemektedir.

Performans sisteminin ulaşılabilir, şeffaf, adil ilkelere dayalı olarak gerçekleştirilmesi de çalışanlar açısından bakıldığında önemli bir kriter olmaktadır.

Eğitimlerin intiyaçlar doğrultusunda sunulması da çalışanların gelişimine direkt katkı sağladığından dolayı çalışanın kendisini işi için yeterli görmesini sağlamakta ve işe bağıılı̆ını arttırmaktadır.

Çalışma şartları ve ortamı kapsamındaki uygulamalar çalışanların sağlığını ve konforunu göz önünde bulundurarak onların iş çıktılarına kolaylıkla ulaşabilmelerini sağlamaktadır.

iletişimin doğru kanallarla yapılması çalışanların bilgiye kolay ulaşmasını sağlar ve bu bilgi alışverişi iş çıktılarına yansıyacağından, çalışanların iş tatmini ve dolayısıyla işe bağlılıkları oluşmuş olur, birlikte işletme ile ilgili bilgilere zamanında ulaşmalarını sağlar. Bu durum da bu uygulamalar çalışanlar üzerinde özellikle örgütsel bağlılığı arttırmakta ve bununla birlikte devreye giren işe aidiyet, işe kendini vererek çalışma duygusunu arttırarak işe bağılığı etkilemektedir. İşveren markası uygulamaları, çalışanları etkilediği kadar işletmelerin bilinirliğini arttırabilir ve işletmenin vizyonu ve misyonunu diğer insanlara daha etkili şekilde aktarmaya yardımcı olabilir. İşletmenin bilinirliği, güvenilirliği, imajı dışarıda ne kadar güçlü olursa, çalışan bulunduğu çalışma ortamını söylemekten o kadar büyük haz alacak ve bu da işe aidiyet duygusunu arttıracaktır.

İşletmeler işe bağıılığı yüksek çalışanlar ile ürün ve hizmetlerini geliştirmekte, yenilemektedir. İşine bağlı çalışanlar işine odaklanmakta ve sonuç odaklı bakış açısı ile çalışmalarını sürdürmektedir. İşletmeler işine bağlı çalışanlarla uzun süreli çalışmak istemektedir. Bu kapsamda da mevcut çalışanlarının işe bağıılıklarını arttırabilmek amacıyla sürekli çalışmalar yapmakta ve işveren markası adı altında yeni uygulamalar tespit edip bağlılığı bu uygulamaları deneyerek arttırmayı hedeflemektedir.

Literatürde işe bağlılık (Garber, 2007; Çakır, 2001; Carmeli, vd., 2004; Kuruüzüm,vd., 2010; Eryılmaz, Doğan 2012; Taufek, vd.2015; Bayrak,2016; Simone, vd., 2017; Kartal, 2017; Schaufeli,2017; Sharma,2017) ve işveren markası ile ilgili (Oğuz,2012; Kara, 2013; Bayrak,2016; Dönmez,2016; Aras,2016 ) birçok çalışma bulunmaktadır. Her iki konuda da ayrı ayrı çalışmalar yapılmış ve bu kavramların işletmeler ve çalışanlar açısından önemine ait bulgular literatürde yer almıştır. Her ne kadar İşe bağlılık ve örgütsel bağlılık arasındaki ilişkiyi inceleyen çalışmalar ile işveren markası ile örgütsel bağııık arasındaki ilişkiyi inceleyen çalışmalar literatürde bulunmaktaysa da işe bağııık ve işveren markasının birlikte değerlendirildiği ve ikisi arasındaki ilişkiyi inceleyen herhangi bir çalışmaya rastlanmamıştır. Literatürdeki bu eksiklik bu çalışmanın çıkış noktasını oluşturmuştur. 
Bu çalışmada işveren markasının işe bağlılık üzerindeki etkisi incelenmiştir. Çalışmanın amacı kapsamında özel sektörde faaliyet gösteren bir beyaz eşya işletmesinin çalışanlarına anket uygulanarak işveren markası ve işe bağııık arasındaki ilişki değerlendirilmeye çalışılmıştır.

\section{Kavramsal Çerçeve}

Bağlılık birçok kişi tarafından incelenmiş olup, kavramsal olarak ilk inceleyenlerden biri olan Becker bağlılığı, herhangi bir konum, faaliyet ya da kişiye bağı olan bir bireyin, bu ortamlara uygun davranışlar sergilemesi ve daha ilgili olması sonucunda taraf olması şeklinde açıklamıştır (Becker, 1960, s.32). Allport, işe bağ|ı̆ı̆ı 'benlilik bağlılığı' olarak açıklamıştır.

Vroom ise benzer bir yaklaşım geliştirmiş bireyin performans dü zeyinin özsaygısını etkilediği düzeyde artan bir olgu olarak açıklamıştır. Vroom'a göre işine yüksek derecede bağlı olan bireyin iş tatmini ve performansı da yüksek olacaktır. İş tatmini ve performans temelde bireylerin yüksek performans göstermelerinin özsaygılarını arttırabilmesiyle ilişkilidir. Diğer bir taraftan yüksek performans gösteren her bireyin işe bağlı olduğunu ya da işe bağlı olan bireylerin sürekli yüksek performans gösterdiğini kabul etmek pek doğru bir yaklaşım olmayacaktır. Kişilerin performansını etkileyen farklı faktörler de vardır. Örneğin, ücret ya da ödül sebebiyle kişiler yüksek performans gösterebilir. (Vroom, 1962, s.161). Lodahl ve Kejner bu konu üzerine 2 farklı yaklaşım geliştirmiştir (Lodahl Kejner, 1965, s.34-35). Birinci yaklaşım, bireyin iş performansının özsaygısını etkileme derecesidir. Diğeri ise, bireyin çalışmayla özdeşleşme derecesi veya çalışmanın yaşamında önemli bir yere sahip olmasıdır. Lodahl ve Kejner işe bağlılığı bireyin sosyalleşme sürecinde öğrendiği çalışmaya yönelik değerlerce belirlendiği hipotezine dayandırmışlardır. Bu açıklama Dubin'in "merkezi yaşam ilgisi” ile ilgili çalışması ile benzerlik göstermektedir. Dubin'e göre bireylerin bazıları tüm ilgilerini çalışmaya yöneltirken, bazıları özel yaşama ve boş zamana yöneltirler, bazılarının ise ne boş zamanlara ne de çalışmaya ilgisi yoktur ve bunlar "ilgi yoğunluğu zayıf” kimselerdir (Dubin, 1956, s.40) .

İşveren Markası kavramı ilk kez 1990 yılında Simon Barrow tarafından kullanılmıştır. Bu kavram kısa bir dönemdir iş hayatında olmasına karşın, büyük bir yankı uyandırmaktadır. Barrow bu kavramın kısa sürede kabul görmesinin sebebini, başarılı bir işveren markasının işe alım sürecinde firmaya kazandırdığı hâkimiyet, çalışan devir hızı, aidiyet hissi, devamsızık oranlarında iyileşme görülmesinden kaynaklı olduğunu belirtmektedir. İşletmenin 'sektöründe en iyi firma', 'Çalışıımak istenen en iyi iş yeri' gibi listelerde yer bulabilmesi durumu hem işletmede çalışanların işlerine olan bağlıık seviyelerine etki edecek hem de işletmeye değer katabilecek potansiyel çalışanları daha rahat çekmesine de olanak sağlayacaktır.

Bir çalışan kendi çalışma ortamını başka bir çalışma ortamı ile kıyasladığında vardığı sonuç aslında çalıştığı işletmenin çalışabileceği en iyi işletme olduğu ise iş̧̧i devir oranı düşecek ve bu da işletmenin karına olacaktır.

İşveren markası, günümüzdeki birçok kavram gibi geliştirilmesi, yeniliklere ayak uydurması gereken bir unsurdur. İşletmelerin işveren markalarıyla birlikte çalışanlarda yarattıkları bağlıı̆ıın kaybolmaması için günlük yapılması gereken bazı işler vardır. Bunlar (Garber, 2007, s.16);

- İşyerinde çalışanların günlük karar ve programlara katılımlarına izin vermek,

- Çalışanların kendi kendilerini yönetebilmeleri için daha fazla fırsatlar bulmak,

- Çalışanların fikir ve önerilerini dinlemek ve en iyi fikri uygulamaya koyabilmenin yollarını araştırmak ve uygulama imkânı sağlamak,

- Temel kurallar çerçevesinde çalışanların hedef ve amaçlarını yapmaya çalışmak, 
- Çalışanların alışıımış temellerde büyük ya da küçük hünerlerinin farkında olmak,

- Daha görünür, ulaşılabilir ve yaklaşılabilir bir yöneticilik tarzı ile yaklaşmak,

- Çalışanların kendi yetenekleri çerçevesinde en iyi şekilde işlerini yapmaları için gerekli araçları sağlamak ve gerekli eğitimleri karşılamak,

- Çalışanların yaşadığı çevre ve iletişimi desteklemek,

Sonuç olarak çalışanların ve organizasyonun arasında karşılıklı güveni sağlama yollarını araştırmak, işletmenin farklı ve çalışana değer katan işveren markası faaliyetleri, çalışanın algısını olumlu etkileyerek çalışanın işe bağlılığının artmasına katkı yapacaktır.

\section{Araştırmanın Yöntemi}

Araştırmada Eskişehir'de faaliyetini devam ettiren bir beyaz eşya firması beyaz yaka çalışanları üzerinde demografik (yaş, deneyim, unvan, departman, mezuniyet), işe bağlılık ve işveren markası değişkenlerini ölçmek üzere sorular içeren bir anket uygulanmıştır. Anket 250 beyaz yaka çalışana uygulanarak tam sayım hedeflenmişse de çalışanların izin dönemleri, sağlık durumları gibi nedenlerle 223 çalışana ulaşılmıştır.

Çalışmada veri toplama aracı olarak 3 bölümden oluşan anket kullanılmıştır. Anket formu üç kısımdan oluşmaktadır. İlk bölümde, çalışanların demografik özelliklerini belirlemeye yönelik olarak; yaş, öğrenim durumu, çalıştıkları departman, pozisyon ve kıdem sorgulanmıştır. İkinci kısımda işveren markası ölçeğine ait ifadelere, üçüncü kısımda ise işe bağlılık ölçeğine ait ifadelere yer verilmiştir. Anketin ikinci ve üçüncü bölümlerindeki işe bağlılık ve işveren markası ölçekleri, Lodahl\&Kejner (1965), Kanungo (1982), Meyer ve Allen (1991), Utrech'in (2002), geliştirdikleri ölçeklerinden çalışma amacı doğrultusunda uyarlanmıştır. Uyarlamada pilot çalışma ile orijinal ölçek soruları çalışanlara sorulmuş ve ilgili olmayanlar çıkartılmıştır. İşletmenin İnsan Kaynakları yöneticisi ile birlikte ölçekte yer alan sorular değerlendirilmiştir.

Araştırmanın yöntemi, çalışmada işveren markasının işe bağııık üzerindeki etkisinin belirlenmesi amaçlandığından ilişkisel tarama modeline dayalıdır. Bu nedenle ölçeklerin boyutlandırılmasında Açıklayıcı Faktör Analizi, ilişkinin ve etkinin belirlenmesinde de Regresyon Analizi kullanılmıştır.

\section{Bulgular}

Çalışmada 223 beyaz yaka çalışanına işveren markası ve işe bağlılık ölçeğine ait soruların bulunduğu anket uygulanmış ve çalışanların demografik özelliklerini belirlemeye yönelik olarak; yaş, öğrenim durumu, çalıştıkları departman, pozisyon ve kıdem sorgulanmıştır. Katılımcıların demografik özelliklerine ilişkin dağılım Tablo 1'de yer almaktadır. (Çelik, 2018, s.29)

Tablo 1: Katılımcıların Demografik Özelliklerine ilişskin Dağılımları

\begin{tabular}{|l|l|l|l|}
\hline Değişken & Sıklık & \% \\
\hline Yaş & $21-26$ & 47 & 21,1 \\
& $26-32$ & 65 & 29,1 \\
& $32-38$ & 56 & 25,1 \\
& $38-44$ & 35 & 15,7 \\
& 44 ve üzeri & 20 & 9,0 \\
& Toplam & $\mathbf{2 2 3}$ & $\mathbf{1 0 0}$ \\
\hline Kıdem & $1-4$ yıl & 86 & 38,6 \\
& $4-7$ yıl & 36 & 16,1 \\
& $7-10$ yıl & 18 & 8,1 \\
& $10-13$ yıl & 16 & 7,2 \\
& 13 yıl ve üzeri & 67 & 30,0 \\
& Toplam & $\mathbf{2 2 3}$ & $\mathbf{1 0 0}$ \\
\hline
\end{tabular}




\begin{tabular}{|l|l|l|l|}
\hline Departman & Ar-Ge & 95 & 42,6 \\
& Üretim & 38 & 17,0 \\
& Üretim Mühendisliği & 31 & 13,9 \\
& Kalite Güvence & 11 & 4,9 \\
& Üretim Planlama & 18 & 8,1 \\
& Mali İşler & 9 & 4,0 \\
& Insan Kaynakları & 21 & 9,4 \\
& Toplam & $\mathbf{2 2 3}$ & $\mathbf{1 0 0}$ \\
\hline Pozisyon & Teknisyen/Teknik Sorumlu/Vardiya Yönetmeni & 30,9 \\
& Sorumlu/Mühendis/Uzman/Kıdemli Uzman & 69 & 65,5 \\
& Sağlık Personeli & 146 & 3,6 \\
& Toplam & $\mathbf{2 2 3}$ & $\mathbf{1 0 0}$ \\
\hline Mezuniyet & Yüksek Lisans & 28 & 12,6 \\
& Lisans & 140 & 62,8 \\
& MYO & 26 & 11,7 \\
& Lise & 29 & 13,0 \\
& Toplam & $\mathbf{2 2 3}$ & $\mathbf{1 0 0}$ \\
\hline
\end{tabular}

Çalışmada çalışanların işe bağıııklarını ve işveren markasına yönelik algılarına ilişkin istatistiki analizler Tablo 2 ve Tablo 3'te yer almaktadır. (Çelik, 2018, s.31-33)

Tablo 2: İşe Bağlılık Ölçeğine Ait Görüşlerin Dağılımı

\begin{tabular}{|c|c|c|c|c|c|c|c|c|c|c|}
\hline \multirow{2}{*}{ IFADELER } & \multicolumn{2}{|c|}{ 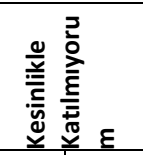 } & \multicolumn{2}{|c|}{ 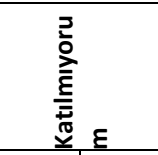 } & \multicolumn{2}{|c|}{$\begin{array}{l}\underline{E} \\
\frac{\mathrm{N}}{\mathrm{N}} \\
\frac{\mathrm{T}}{\pi} \\
\frac{\pi}{\pi} \\
\end{array}$} & \multicolumn{2}{|c|}{ 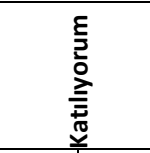 } & \multicolumn{2}{|c|}{ 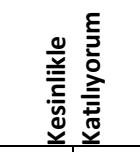 } \\
\hline & $f$ & $\%$ & $f$ & $\%$ & $f$ & $\%$ & $f$ & $\%$ & $f$ & $\%$ \\
\hline $\begin{array}{l}\text { Verilen görevler yeteneklerime } \\
\text { uygundur. }\end{array}$ & 4 & 1,8 & 11 & 4,9 & 47 & 21,1 & 128 & 57,4 & 33 & 14,8 \\
\hline Yaptığım iş çıktıları, tatmin edicidir. & 7 & 3,1 & 15 & 6,7 & 51 & 22,9 & 117 & 52,5 & 33 & 14,8 \\
\hline $\begin{array}{l}\text { Yaptığım iş, şirketin iş sonuçlarına } \\
\text { katkı sağlamaz. }\end{array}$ & 84 & 37,7 & 101 & 45,3 & 19 & 8,5 & 9 & 4,0 & 10 & 4,5 \\
\hline $\begin{array}{l}\text { İşimde yetenek ve becerilerimi } \\
\text { kullanıyorum. }\end{array}$ & 2 & 0,9 & 11 & 4,9 & 32 & 14,3 & 123 & 55,2 & 55 & 75,3 \\
\hline $\begin{array}{l}\text { Yaptığım işin kişisel gelişimime katkısı } \\
\text { yoktur. }\end{array}$ & 39 & 17,5 & 112 & 50,2 & 47 & 21,1 & 17 & 7,6 & 8 & 3,6 \\
\hline $\begin{array}{l}\text { Yöneticim işimi yapabilmek için } \\
\text { ihtiyaç duyduğum bilgileri zamanında } \\
\text { verir. }\end{array}$ & 3 & 1,3 & 19 & 8,5 & 54 & 24,2 & 119 & 53,4 & 28 & 12,6 \\
\hline $\begin{array}{l}\text { Yöneticim karar alırken astlarının } \\
\text { görüşlerini dikkate alır. }\end{array}$ & 3 & 1,3 & 16 & 7,2 & 55 & 24,7 & 123 & 55,2 & 26 & 11,7 \\
\hline $\begin{array}{l}\begin{array}{l}\text { Yöneticim şirketteki } \\
\text { sonuçlar } \\
\text { bilgilendirir. }\end{array} \\
\text { hakkında }\end{array}$ & 0 & 0 & 26 & 11,7 & 38 & 17,0 & 125 & 56,1 & 34 & 15,2 \\
\hline $\begin{array}{l}\text { Yöneticim bölüm başarılarını } \\
\text { çalışanlar ile paylaşır. }\end{array}$ & 0 & 0 & 18 & 8,1 & 36 & 16,1 & 118 & 52,9 & 51 & 22,9 \\
\hline $\begin{array}{l}\text { Yöneticim işle ilgili problemlerimle } \\
\text { ilgilenir. }\end{array}$ & 2 & 0,9 & 12 & 5,4 & 43 & 19,3 & 112 & 50,2 & 54 & 24,2 \\
\hline $\begin{array}{l}\text { İşimle ilgili sorumluluklarımın ne } \\
\text { olduğunu biliyorum. }\end{array}$ & 4 & 1,8 & 8 & 3,6 & 117 & 7,6 & 18 & 52,9 & 76 & 34,1 \\
\hline $\begin{array}{l}\text { İşimle ilgili benden ne beklendiğini } \\
\text { biliyorum. }\end{array}$ & 7 & 3,1 & 6 & 2,7 & 27 & 12,1 & 118 & 52,9 & 65 & 29,1 \\
\hline $\begin{array}{l}\text { Gün içerisinde gereksiz işlerle } \\
\text { uğraşırım. }\end{array}$ & 35 & 15,7 & 64 & 28,7 & 54 & 24,2 & 52 & 23,3 & 18 & 8,1 \\
\hline Farklı amaçlara yönelik işler yaparım. & 12 & 5,4 & 30 & 13,5 & 52 & 23,3 & 102 & 45,7 & 27 & 12,1 \\
\hline
\end{tabular}


Eskişehir Osmangazi Üniversitesi IïBF Dergisi

\begin{tabular}{|l|c|c|c|c|c|c|c|c|c|c|}
\hline $\begin{array}{l}\text { Farklı işleri aynı anda yapmak } \\
\text { zorunda kalırım. }\end{array}$ & 9 & 4,0 & 14 & 6,3 & 21 & 9,4 & 108 & 48,4 & 71 & 31,8 \\
\hline $\begin{array}{l}\text { X Şirketinde kendimi ailenin bir ferdi } \\
\text { olarak hissediyorum. }\end{array}$ & 5 & 2,2 & 20 & 9,0 & 58 & 26,0 & 104 & 46,6 & 36 & 16,1 \\
\hline
\end{tabular}

Tablo 3: İşveren Markası Ölçeğine Ait Görüşlerin Dağılımı

\begin{tabular}{|c|c|c|c|c|c|c|c|c|c|c|}
\hline \multirow[t]{2}{*}{ IFADELER } & \multicolumn{2}{|c|}{ 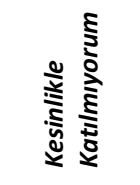 } & \multicolumn{2}{|c|}{ 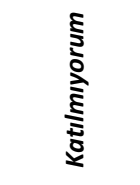 } & \multicolumn{2}{|c|}{ 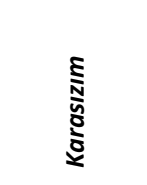 } & \multicolumn{2}{|c|}{ 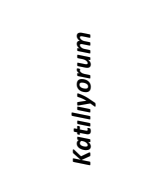 } & \multicolumn{2}{|c|}{ 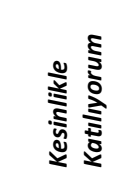 } \\
\hline & $f$ & $\%$ & $f$ & $\%$ & $f$ & $\%$ & $f$ & $\%$ & $f$ & $\%$ \\
\hline $\begin{array}{l}\text { X Şirketi çalışmak istediğim firmalar } \\
\text { arasında ön sıradadır. }\end{array}$ & 4 & 1,8 & 8 & 3,6 & 56 & 25,1 & 93 & 41,7 & 62 & 27,8 \\
\hline $\begin{array}{l}\text { Iş arayan arkadaşlarımı } X \text { Şirketinde } \\
\text { çalışmaları için yönlendiririm. }\end{array}$ & 2 & 0,9 & 9 & 4,0 & 23 & 10,3 & 131 & 58,7 & 58 & 26,0 \\
\hline $\begin{array}{l}\text { Aynı imkanlarda bir iş teklifi alsam da X } \\
\text { Şirketinde çalışmaya devam ederim. }\end{array}$ & 3 & 1,3 & 12 & 5,4 & 44 & 19,7 & 109 & 48,9 & 55 & 24,7 \\
\hline $\begin{array}{l}X \text { Şirketinin toplumda saygıdeğer bir } \\
\text { yeri vardır. }\end{array}$ & 7 & 3,1 & 9 & 4,0 & 63 & 28,3 & 87 & 39,0 & 57 & 25,6 \\
\hline $\begin{array}{l}\text { X Şiketi çalışanlarına değer veren bir } \\
\text { şirkettir. }\end{array}$ & 3 & 1,3 & 2 & 0,9 & 12 & 5,4 & 98 & 43,9 & $\begin{array}{c}10 \\
8 \\
\end{array}$ & 48,4 \\
\hline X Şirketi global bir markadır. & 6 & 2,7 & 20 & 9,0 & 55 & 24,7 & 106 & 47,5 & 36 & 16,1 \\
\hline $\begin{array}{l}\text { X Şirketi emekli olabileceğim bir } \\
\text { şirkettir. }\end{array}$ & 3 & 1,3 & 6 & 2,7 & 9 & 4,0 & 95 & 42,6 & $\begin{array}{c}11 \\
0\end{array}$ & 49,3 \\
\hline $\begin{array}{l}\text { Isse alımda objektif kriterler ile } \\
\text { değerlendirildiğimi düşünüyorum. }\end{array}$ & 5 & 2,2 & 18 & 8,1 & 74 & 33,2 & 91 & 40,8 & 35 & 15,7 \\
\hline $\begin{array}{l}\text { Işe alımda yöneticilerin arkadaş veya } \\
\text { tanıdıkları öncelikli değerlendirilir. }\end{array}$ & 3 & 1,3 & 7 & 3,1 & 43 & 19,3 & 120 & 53,8 & 50 & 22,4 \\
\hline $\begin{array}{l}\text { Türk firması olduğu için X Şirketinde } \\
\text { çalışmayı tercih ederim. }\end{array}$ & 11 & 4,9 & 71 & 31,8 & 77 & 34,5 & 49 & 22,0 & 15 & 6,7 \\
\hline X Şirketi gelecekte de başarılı olacaktır. & 15 & 6,7 & 26 & 11,7 & 43 & 19,3 & 103 & 46,2 & 36 & 16,1 \\
\hline $\begin{array}{l}\text { Şirketimden çevreme gururla söz } \\
\text { ederim. }\end{array}$ & 3 & 1,3 & 9 & 4,0 & 28 & 12,6 & 123 & 55,2 & 60 & 26,9 \\
\hline $\begin{array}{l}\text { Çalışanların performansı şeffaf } \\
\text { değerlendirilir. }\end{array}$ & 25 & 11,2 & 35 & 15,7 & 79 & 35,4 & 66 & 29,6 & 18 & 8,1 \\
\hline $\begin{array}{l}\text { Çalışanların performansı objektif } \\
\text { değerlendirilir. }\end{array}$ & 22 & 9,9 & 35 & 15,7 & 87 & 39,0 & 62 & 27,8 & 17 & 7,6 \\
\hline $\begin{array}{l}\text { Kariyer olanakları çalışanların } \\
\text { başarısına göre sunulur. }\end{array}$ & 22 & 9,9 & 33 & 14,8 & 92 & 41,3 & 64 & 28,7 & 12 & 5,4 \\
\hline Çalışma ortamı sağlığa uygundur. & 12 & 5,4 & 18 & 8,1 & 37 & 16,6 & 116 & 52,0 & 40 & 17,9 \\
\hline Şirket yeni teknolojilerden yararlanır. & 3 & 1,3 & 10 & 4,5 & 39 & 17,5 & 126 & 56,5 & 45 & 20,2 \\
\hline Oryantasyon eğitimleri yetersizdir. & 23 & 10,3 & 71 & 31,8 & 64 & 28,7 & 45 & 20,2 & 20 & 9,0 \\
\hline Eğitimler, ihtiyaçlara göre planlanır. & 7 & 3,1 & 30 & 13,5 & 70 & 31,4 & 97 & 43,5 & 19 & 8,5 \\
\hline Yönetim eğitime katılımı destekler. & 8 & 3,6 & 13 & 5,8 & 48 & 21,5 & 112 & 50,2 & 42 & 18,8 \\
\hline $\begin{array}{l}\text { Şirkette takdir ve ödüllendirme objektif } \\
\text { olarak yapılır. }\end{array}$ & 35 & 11,2 & 25 & 15,7 & 85 & 38,1 & 65 & 29,1 & 13 & 5,8 \\
\hline $\begin{array}{l}\text { Şirketle ilgili elde edilen başarılar } \\
\text { çalışanlar ile paylaşılır. }\end{array}$ & 5 & 2,2 & 18 & 8,1 & 62 & 27,8 & 113 & 50,7 & 25 & 11,2 \\
\hline Departmanımız içinde iş birliği vardır. & 2 & 0,9 & 15 & 6,7 & 43 & 19,3 & 121 & 54,3 & 42 & 18,8 \\
\hline Departmanlar arası iş birliği yoktur. & 22 & 9,9 & 81 & 36,3 & 61 & 27,4 & 47 & 21,1 & 12 & 5,4 \\
\hline $\begin{array}{l}\text { Departmanlar, şirket başarısı için } \\
\text { birlikte çalışır. }\end{array}$ & 10 & 4,5 & 19 & 8,5 & 79 & 35,4 & 97 & 43,5 & 18 & 8,1 \\
\hline
\end{tabular}




\begin{tabular}{|l|c|c|c|c|c|c|c|c|c|c|}
\hline $\begin{array}{l}\text { Diğer departmanların yaptı̆̆ı işler } \\
\text { hakkında bilgim vardır. }\end{array}$ & 8 & 3,6 & 23 & 10,3 & 62 & 27,8 & 108 & 48,4 & 22 & 9,9 \\
\hline $\begin{array}{l}\text { Şirkette herkes düşündüklerini açıkça } \\
\text { söyleyebilir. }\end{array}$ & 14 & 6,3 & 29 & 13,0 & 89 & 39,9 & 78 & 35,0 & 13 & 5,8 \\
\hline $\begin{array}{l}\text { Şirket hakkındaki bilgileri söylentilerden } \\
\text { öğrenirim. }\end{array}$ & 25 & 11,2 & 71 & 31,8 & 69 & 30,9 & 48 & 21,5 & 10 & 4,5 \\
\hline
\end{tabular}

Çalışmada çalışanların işe bağlılıklarını ve işveren markasına yönelik algılarının boyutlandırılması amacıyla her iki ölçek Açıklayıcı Faktör Analizine (AFA) tabi tutulmuştur. AFA sonuçlarına göre işe bağlılık 3 faktör, işveren markası 5 faktör altında toplanmıştır. AFA sonucunda belirlenen faktörler içerdikleri ifadelere ve literatüre dayalı olarak isimlendirilmiştir.

Daha sonra işveren markasının işe bağlılık üzerindeki etkisinin belirlenmesi amacı doğrultusunda öncelikle elde edilen faktörler dikkate alınmaksızın Basit Doğrusal regresyon analizi, daha sonra da işveren markası faktörlerinin bağımsız değişken olarak alınmasıyla çoklu doğrusal regresyon analizi ile faktörlerin etkileri dikkate alınarak incelenmiştir. Çalışmada yapılan tüm istatistiksel analizlerde anlam düzeyi \%5 olarak alınmış ve SPSS 20.0 paket programından yararlanılmıştır.

\subsection{Açıklayıcı Faktör Analizi (AFA) Sonuçları}

Açıklayıcı faktör analizi (AFA) aralarında ilişki bulunduğu düşünülen çok sayıdaki değişkenin arasındaki ilişkilerin yorumlanmasını kolaylaştırmak için değişkenleri gruplayarak sayısını azaltmak, özetlemektir. (Tatlıdil, 1996; Korkmaz, 2000) Araştırmada işe bağııık ve işveren markası için ayrı ayrı AFA yapılarak değişkenler özetlenmiştir.

Çalışmada öncelikle işe bağlıık ve işveren markası ifadelerinin güvenilirlik analizi ile güvenilir olup olmadığı tespit edilmiştir. Güvenirlilik analizi ankete verilen yanıtların tutarlılığını ölçmek için yapılmaktadır. Daha sonra verilerin faktör analizine uygunluğu KMO (Kaiser Mayer Olkin)Bartlett Testi ile belirlenmiştir. KMO değeri 1'e ne kadar yakınsa evren faktör analizine o kadar uygundur. Faktör analizi uygulayabilmek için KMO değeri 0,5 değerinin üzerinde olmalıdır. (Patır, 2009, s.73); Bartlett testi değişkenler arasındaki korelasyonun yeterli olup olmadığına karar verir. $P$ değeri < 0,05 ise veriler faktör analizi için uygundur. Tablo 2'de İşe Bağlılık Ölçeğine ait AFA Sonuçları, Tablo 4'te İşveren Markası Ölçeğine ait AFA Sonuçları yer almaktadır.

Tablo 4: Işse Bağlılık Ölçeğine (IBÖ) ait AFA Sonuçları

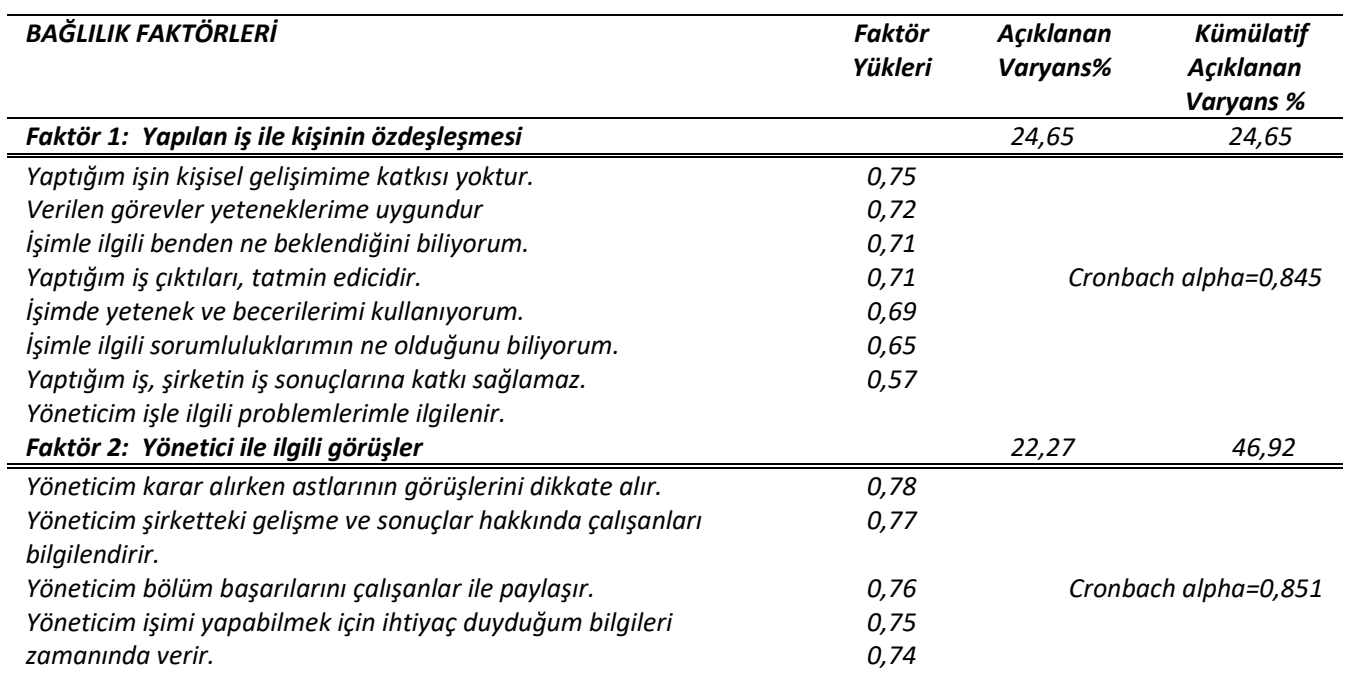


Farklı amaçlara yönelik işler yaparım.

Gün içerisinde gereksiz işlerle uğraşırım.

0,64

KMO=0,847 $\quad p=0,000$

Varyans Açıklama Yüzdesi=\%59,142

İşe bağlılık ölçeğinin (IBÖ) AFA sonuçlarına göre; işe bağlılıkla ilgili 15 maddenin Cronbach Alpha değeri $0,776>0,7$ olduğundan güvenilir olduğu söylenebilir. Verilerin normal dağılıma uygunluğu belirlenmiştir.

$\mathrm{H}_{0}$ : İşe bağlılık ölçeği maddeleri normal dağılmıştır.

$\mathrm{H}_{1}$ : İşe bağlılık ölçeği maddeleri normal dağılmamıştır.

Analizler sonucunda KMO değeri 0,847 (1'e yakın bir değer), Bartlett $p=0,000$ olduğu için verilerin normal dağıldığı ve faktör analizi için uygun olduğu görülmektedir. AFA sonucunda işe bağlılık ile ilgili özdeğerleri 1'in üzerinde olduğu için üç temel faktör belirlenmiştir. Bu üç faktör toplamda işe bağlılık ölçeğinin \%59,142'sini açıklamaktadır. Ölçeğin güvenilirliği ise \%77,6'dır (Cronbach alpha=0,776).

IBÖ için elde edilen faktörler ayrı ayrı incelendiğinde (Tablo 1);

- Faktör 1: "Yapılan iş ile kişinin özdeşleşmesi" faktöründe yer alan ifadeler (Faktör 1) Cronbach Alpha değeri 0,845>0,5 olduğu için güvenilirdir. Bu faktör işe bağlılık ölçeğinin $\% 24,65$ 'ini açıklamaktadır.

Faktörlerde yer alacak ifadelerin faktör yüklerinin en az \%50 olması beklenmektedir. Başka bir deyişle faktör içerisinde yer alan ifadenin o faktörün en az $\% 50$ 'sini açıklaması beklenmektedir. Faktör 1 içerisinde yer alan ifadelerin faktör yüklerine bakıldığında;

"Yapılan iş ile kişinin özdeşleşmesi" faktörünün "Yaptığım işin kişisel gelişimime katkısı yoktur." ifadesi \%75'ini, "Verilen görevler yeteneklerime uygundur." \%72'sini, "İşimle ilgili benden ne beklendiğini biliyorum." \%71'ini, "Yaptığım iş çıktıları, tatmin edicidir." \%71'ini, "İşimde yetenek ve becerilerimi kullanıyorum." \%69'unu, "İşimle ilgili sorumluluklarımın ne olduğunu biliyorum." \%65'ini, "Yaptığım iş, şirketin iş sonuçlarına katkı sağlamaz." \%57'sini açıklamaktadır.

- Faktör 2: "Yönetici ile ilgili görüşler" faktöründe (Faktör 2) Cronbach Alpha değeri $0,851>0,5$ olduğu için ifadelerin güvenirliliğinden bahsedilebilir. Bu faktör işe bağlılık ölçeğinin \%22,27'sini açıklamaktadır. Faktör 2'de yer alan ifadelere bakıldığında;

"Yöneticim karar alırken astlarının görüşlerini dikkate alır." ifadesi \%78'ini, "Yöneticim şirketteki gelişme ve sonuçlar hakkında çalışanları bilgilendirir." \%77'sini, "Yöneticim bölüm başarılarını çalışanlar ile paylaşır." \%76'sını, "Yöneticim işle ilgili problemlerimle ilgilenir." \%75'ini, "Yöneticim işimi yapabilmek için ihtiyaç duyduğum bilgileri zamanında verir." $\% 74$ 'ünü açıklamaktadır.

- Faktör 3: "İşin amacı ve anlamlılığı” faktöründe (Faktör 3) Cronbach Alpha değeri $0,641<0,5$ olarak belirlenmiştir. $0,5^{\prime}$ ten küçük olmadığı için ifadelerin güvenilir olduğundan söz edilebilir. Bu faktör işe bağlııı ölçeğinin \%12,22'sini açıklamaktadır. Faktör 3' ün “Farklı işleri aynı anda yapmak zorunda kalırım." ifadesi \%79'unu, "Farklı amaçlara yönelik işler yaparım." \%79'unu, "Gün içerisinde gereksiz işlerle uğraşırım." \%64'ünü açıklamaktadır (Çelik, 2018, s.48-49). 
İşveren Markası ölçeğinin (iMÖ) AFA sonuçlarına göre (Tablo 5); AFA sonucunda 23 maddeden oluşan iMÖ için belirlenen 5 faktör, işveren markası algısına yönelik değişkenliğin \%65,44'ünü açıklamaktadır. Söz konusu faktörler içerdikleri maddelerle ilişkilendirilerek literatüre paralel şekilde tarafımızdan isimlendirilmiştir. Verilerin normal dağılıma uygunluğu belirlenmiştir.

$\mathrm{H}_{0}$ : İşveren markası ölçeği maddeleri normal dağılmıştır.

$\mathrm{H}_{1}$ : İşveren markası ölçeği maddeleri normal dağılmamıştır.

Barlett testi sonucu $(p>0,000)$ değerine göre veriler normal dağılmıştır ve Kaiser-Meyer-Olkin örneklem değeri 0,918 olarak gerçekleşmiştir. Ölçeğin güvenilirliği ise \%93 'tür (Cronbach alpha=0,930).

Tablo 5: İşveren Markası Ölçeğine (iMÖ)ait AFA Sonuçları

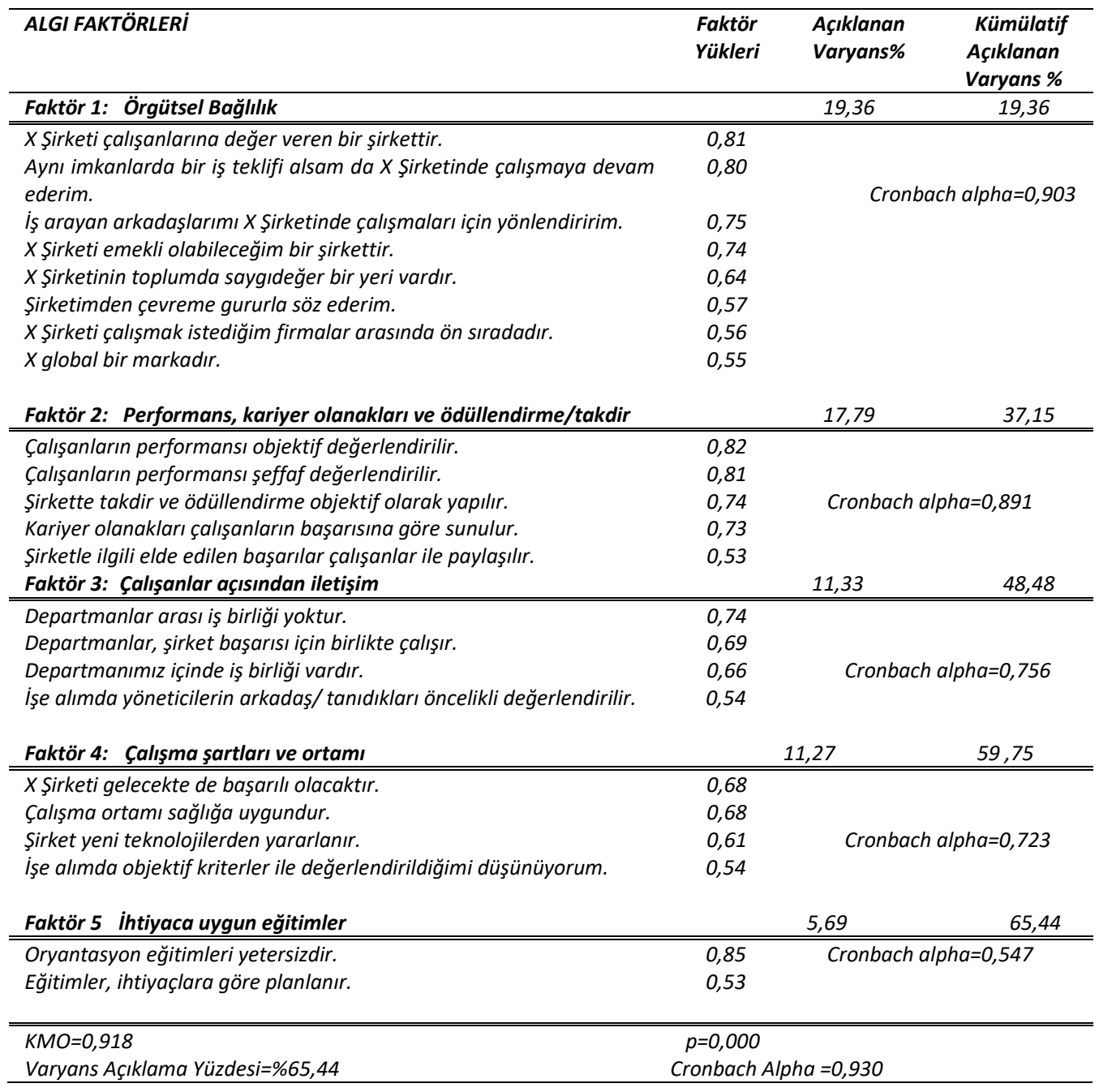


iMÖ için elde edilen faktörler ayrı ayrı incelendiğinde (Tablo 2) (Çelik, 2018, s.50-51);

- Faktör 1: "Örgütsel Bağlılık" faktörü işveren markası ölçeğinin \%19,36'sını açıklamaktadır. Bu alt ölçeğin güvenilirliği \%903 ile oldukça yüksektir.

"Örgütsel Bağlılık" faktörünün "X Şirketi çalışanlarına değer veren bir şirkettir." ifadesi \%81' ini, "Aynı imkanlarda bir iş teklifi alsam da X Şirketinde çalışmaya devam ederim." \%80'ini, "Iş arayan arkadaşlarımı X Şirketinde çalışmaları için yönlendiririm." \%75'ini, "X Şirketi emekli olabileceğim bir şirkettir." \%74'ünü, "X Şirketinin toplumda saygıdeğer bir yeri vardır." \%64'ünü, "Şirketimden çevreme gururla söz ederim." \%57'sini, "X Şirketi çalışmak istediğim firmalar arasında ön sıradadır." \%56'sını, "X global bir markadır." \%55'ini açıklamaktadır.

- Faktör 2: "Performans, kariyer olanakları ve ödüllendirme/takdir" faktöründe Cronbach Alpha değeri 0,891dir. Bu faktör işveren markası ölçeğinin \%17,79'unu açıklamaktadır.

Faktör 2'deki "Çalışanların performansı objektif değerlendirilir." ifadesi \%82'sini, "Çalışanların performansı şeffaf değerlendirilir." \%81'ini, "Şirkette takdir ve ödüllendirme objektif olarak yapılır." \%74'ünü, "Kariyer olanakları çalışanların başarısına göre sunulur." \%73'ünü, "Şirketle ilgili elde edilen başarılar çalışanlar ile paylaşılır." \%53'ünü açıklamaktadır

- Faktör 3: "Çalışanlar açısından iletişim" faktöründe (Faktör 3) Cronbach Alpha değeri 0,756 dır. Bu faktörün varyans açıklama yüzdesi 11,33'tür.

Faktör 3'ün "Departmanlar arası iş birliği yoktur." ifadesinin faktör yükü \%74, "Departmanlar, şirket başarısı için birlikte çalışır." ifadesinin \%69, "Departmanımız içinde iş birliği vardır." \%66, "Işse alımda yöneticilerin arkadaş veya tanıdıkları öncelikli değerlendirilir." \%54 olarak gerçekleşmiştir. 'ünü açıklamaktadır.

- Faktör 4: "Çalışma şartları ve ortamı" faktöründe (Faktör 4) Cronbach Alpha değeri $0,723>0,5$ olduğu için ifadeler güvenilirdir. Bu faktör işveren markası ölçeğinin \%11,27'sini açıklamaktadır.

Faktör 4'deki maddelerin faktör yükleri ise şu şekildedir: "X Şirketi gelecekte de başarılı olacaktır." ifadesinin \%68, "Çalışma ortamı sağlığa uygundur." Ifadesinin \%68, "Şirket yeni teknolojilerden yararlanır." ifadesinin \%61, "işe alımda objektif kriterler ile değerlendirildiğimi düşünüyorum." maddesinin faktör yükü ise \%54'tür

- Faktör 5: "ihtiyaca uygun eğitimler" (faktör 5) Cronbach Alpha değeri 0,547 olarak belirlenmiştir. İfadelerin güvenilirliğinden söz edebiliriz. Bu faktör iMÖ’deki değişkenliğin \%5,69'unu açıklamaktadır.

Faktör 5'in "Oryantasyon eğitimleri yetersizdir." ifadesinin faktör yükü \%85, "Eğitimler, ihtiyaçlara göre planlanır." Ifadesinin ise faktör yükü \%53'tür.

\subsection{Regresyon Analizi}

Regresyon analizi, iki ya da daha çok değişken arasındaki ilişkiyi ölçmek için kullanılan analiz metodudur. Çalışmada; işveren Markası uygulamalarının çalışanların işe bağlııkları üzerine etkisi olabileceği düşünüldüğünden bu iki değişken arasındaki ilişki regresyon analizi ile tespit edilmiştir. Hipotez aşağıdaki şekilde kurulmuştur.

$\mathrm{H}_{0}$ : Kurulan regresyon anlamlıdır.

$\mathrm{H}_{1}$ : Kurulan regresyon modeli anlamlı değildir. 
İse Bağlılık ve İşveren Markası ilişkisini ortaya koyan basit doğrusal regresyon analizi sonuçları Tablo 6 ve Tablo 7'de verilmiştir (Çelik, 2018, s.55).

Tablo 6: Basit Doğrusal Regresyon Analizi Sonuçları

\begin{tabular}{lccccc}
\hline MODEL & Kareler Toplamı & s.d & Kareler Ortalaması & $\mathrm{F}$ & $p$ \\
& & & & \\
\hline \hline Regresyon & 22,399 & 1 & 22,399 & 211,5 & 0,000 \\
Artık & 23,400 & 221 & 0,106 & 44 & \\
Toplam & 45,799 & 222 & & & \\
\hline \hline$R=0,699$ & $\mathrm{R}^{2}=0,489$ & Düzeltilmiş $\mathrm{R}^{2}=0,487$ & Standart sapma=0,3254 \\
\hline \hline
\end{tabular}

Tablo 7: Iş̧e bağlıık ile işveren markası ilişkisine ait Basit Doğrusal Regresyon Modeli Sonuçları

\begin{tabular}{llllll}
\hline MODEL & B & Standart hata & Beta & $\mathrm{t}$ & $p$ \\
& & & & \\
\hline \hline Sabit & 1,643 & 0,147 & & 11,150 & 0,000 \\
işveren Markası & 0,598 & 0,041 & 0,699 & 14,545 & 0,000
\end{tabular}

Tablo 6 ve Tablo 7'den görüldüğü gibi;

- İşveren markası algısı, çalışanların işe bağlılığındaki değişimin \%48,7 oranında açıklamaktadır.

- İşveren markası işe bağlılığı anlamlı bir şekilde açıklamaktadır $(p=0,000<0,05)$.

- Çalışanların işveren markası uygulamalarından memnuniyetleri arttıkça işe bağlılıkları da artmaktadır. Çalışanların işveren markası uygulamalarına yönelik 1 puanlık olumlu algıları işe bağlılıklarında 0,699 puan artışına neden olmaktadır.

AFA ile elde edilen IMÖ faktörlerinin ayrı etkilerinin olabileceği düşüncesiyle her bir ìÖ faktörünün birer bağımsız değişken alınmasıyla çoklu doğrusal regresyon analizi ile bu faktörlerin işe bağlılık üzerindeki etkileri incelenmiştir. Hipotez aşağıdaki gibi kurulmuştur.

$\mathrm{H}_{0}$ : Kurulan regresyon anlamlıdır.

$\mathrm{H}_{1}$ : Kurulan regresyon modeli anlamlı değildir.

Analiz sonucuna göre kurulan regresyon modeli anlamlıdır ( $p$ değeri<0,05).

Çoklu doğrusal analiz sonuçları Tablo 8 ve Tablo 9'da verilmiştir.

Tablo 8: Çoklu Doğrusal Regresyon Analizi Sonuçları

\begin{tabular}{lccccc}
\hline MODEL & Kareler Toplamı & s.d & Kareler Ortalaması & $\mathrm{F}$ & $P$ \\
& & & & & \\
\hline \hline Regresyon & 23,307 & 5 & 4,661 & 44,972 & 0,000 \\
Artık & 23,400 & 217 & 0,104 & & \\
Toplam & 45,799 & 222 & & Standart sapma=0,32195 \\
\hline \hline$R=0,713$ & $\mathrm{R}^{2}=0,509$ & Düzeltilmiş $\mathrm{R}^{2}=0,498$ & & \\
\hline \hline
\end{tabular}


Eskişehir Osmangazi Üniversitesi ïBF Dergisi

Tablo 9: İşe bağlılık ile işveren markası b-boyutlarına ait Çoklu Doğrusal Regresyon Modeli Sonuçları

\begin{tabular}{|c|c|c|c|c|c|}
\hline MODEL & B & $\begin{array}{l}\text { Standart } \\
\text { hata }\end{array}$ & Beta & $\mathrm{t}$ & $P$ \\
\hline Sabit & 1,691 & 0,148 & & 11,148 & 0,000 \\
\hline Faktör1: Örgütsel bağlılık & 0,206 & 0,047 & 0,301 & 4,394 & 0,000 \\
\hline $\begin{array}{l}\text { Faktör 2: Performans, kariyer olanakları ve } \\
\text { ödüllendirme/takdir }\end{array}$ & 0,053 & 0,036 & 0,101 & 1,471 & 0,143 \\
\hline Faktör 3: Çalışanlar açısından iletişim & 0,174 & 0,042 & 0,267 & 4,104 & 0,000 \\
\hline Faktör 4: Çalışma şartları ve ortamı & 0,097 & 0,041 & 0,153 & 2,359 & 0,019 \\
\hline Faktör 5: İhtiyaca uygun eğitimler & 0,028 & 0,029 & 0,053 & 0,955 & 0,341 \\
\hline
\end{tabular}

Tablo 8 ve Tablo 9'dan görüldüğü gibi;

- İşveren markası faktörleri işe bağııı̆ı \%49,8 oranında (ve istatistiksel olarak anlamlı şekilde) açıklamaktadır.

- İşveren markası faktörleri ile işe bağlılık arasında pozitif yönde güçlü denebilecek bir ilişki söz konusudur. $(R=0,713)$

- Çalışanların işveren markası faktörleri arasında yer alan örgütsel bağlılık (Faktör 1), çalışanlar açısından iletişim (Faktör 3), çalışma şartları ve ortamı ile ilgili uygulamalardan (Faktör4) memnuniyet düzeyleri arttıkça işe bağlııkları da artmaktadır ( $p$ değerleri<0,05). Bununla birlikte Performans, kariyer olanakları ve ödüllendirme/takdir, ihtiyaca uygun eğitimler faktörleri ile ilgili çalışanlardaki memnuniyet artışının işe bağlılıklarındaki olumlu etkisi istatistiksel olarak anlamlı bulunmamıştır ( $p$ değerleri $>0,05$ ).

- Iş̧e bağlıık üzerinde İstatistiksel olarak anlamlı etkiye sahip işveren markası faktörleri içinde en fazla etkiye sahip olan faktör, örgütsel bağlılıktır. Çalışanların örgütlerine olan bağlılıklarındaki 1 puanlık olumlu algı artışı, işe bağlılıklarında 0,206 puanlık artışı oluşturmaktadır.

\section{Sonuç}

Çalışanların işe bağlııkları üzerinde işveren markasının etkisini belirlemeye yönelik bu çalışmada; bir beyaz eşya firmasının 223 beyaz yaka çalışanına işletmenin işveren markası uygulamalarının işe bağııı̆a etkisini tespit edebilmek amacıyla anket uygulanmıştır.

İşe bağlılık ölçeği 3 faktör altında, işveren markası ölçeği 5 faktör altında toplanmıştır. İşe bağlılık ölçeğine ait faktörler: Yapılan iş ile kişinin özdeşleşmesi, Yönetici ile ilgili görüşler, İşin amacı ve anlamlılığı şeklinde; İşveren Markası ölçeğine ait faktörler: Örgütsel Bağlılık, Performans, kariyer olanakları ve ödüllendirme/takdir, Çalışanlar açısından iletişim, Çalışma şartları ve ortamı, ìtiyaca uygun eğitimler olarak isimlendirilmiştir.

Araştırmanın temel amacı olan işe bağlılık ve işveren markası arasındaki ilişki regresyon analizi ile belirlenmiştir. Regresyon analizi sonuçlarına göre işe bağlılıkla işveren markası uygulamaları arasında pozitif yönde anlamlı bir ilişki vardır. Ayrıca işveren markasıyla ilgili algıla, işe bağııı̆ı \%48,7 oranında açıklamaktadır. İşveren markası adı altında yapılan uygulamalar çalışanların işe bağlılıklarının artmasına etki etmektedir. Ayrıca işveren markası faktörlerinin işe bağlılığa etkisi çoklu doğrusal regresyon analizi ile incelenmiştir. Çalışanların örgütsel bağlılık, çalışanlar açısından iletişim, çalışma şartları ve ortamı ile ilgili uygulamalardan memnuniyet 
düzeyleri arttıkça işe bağlılıkları da artmaktadır. Bununla birlikte çalışanların performans, kariyer olanakları ve ödüllendirme/takdir, intiyaca uygun eğitimler faktörleri ile ilgili işveren markası uygulamalarından kaynaklı memnuniyet artışının işe bağıılığa etkisi istatistiksel olarak anlamlı bulunmamıştır. Özellikle örgütsel bağlılığın yüksekliği, işe bağlılığa olumlu olarak yansımakta ve diğer faktörlerden daha fazla etki yapmaktadır. Dolayısıyla çalışanlarında işe bağlılığı yükseltmek isteyen işletmeler, örgütsel bağlılığı yüksek işveren markası oluşturmaya önem vermelidirler.

Gelecekte yapılacak işe bağlıık ve işveren markası ile ilgili çalışmalarla (örneğin; işveren markası adı altındaki uygulamaların çalışanların demografik özelliklerine göre farklılığının işe bağlııklarındaki etkisinin incelenmesi, elde edilen faktörler bakımından çalışanların demografik özelliklerine göre farklılığı v.b) gerek alan yazına gerekse işletme yönetimlerine önemli bilgiler sağlanarak katkılar yapılabilir. Çalışanların demografik özelliklerine göre çeşitli analizlerin başka bir çalışmada yapılması planlanmaktadır. 


\section{Kaynaklar}

Aras Mustafa, Bayraktaroğlu Serkan, (2016) “İsveren Markası Bağlamında Fonksiyonel Ve Duygusal Faydanın Örgütsel Bağlılığa Etkisi", https://www.researchgate.net/publication/304246371.

Bakker Arnold, Schaufeli Wilmar , (2010) "The Conceptualization and Measurement of Work Engagement", https://www.researchgate.net/publication/48320081 (January,2010).

Bayrak Muhammet Emin, (2016) “işsveren Markasına Yönelik Uygulamaların Örgütsel Bağlılık Üzerine Etkisi Ve Medikal Sektöründe Bir Uygulama”, İstanbul Aydın Üniversitesi Sosyal Bilimler Enstitüsü Yüksek Lisans Tezi.

Bilgiç Hasan Fikri, (2017) “Örgütsel Bağlıık Iş̧ Tatmini İlişkisi”, Uludağ Üniversitesi, Sosyal Bilimler Enstitüsü, Yönetim ve Organizasyon Dalı, Tezli Yüksek Lisans Tezi , pp. 35-49.

Carmeli Abraham, Anat Freund, (2004) “Work Commitment, Job Satisfaction, and Job Performance: an Empirical Investigation", International Journal of Organization Theory and Behavior, 6(4), p. 289-309.

Çakır Özlem, (2001) "işse Bağııık Olgusu ve Etkileyen Faktörler" Seçkin Yayıncılık.

De Simone Silvia, Planta Anna, Gianfranco Cicotto, (2018) "The role of job satisfaction, work engagement, self-efficacy and agentic capacities on nurses' turnover intention and patient satisfaction", Applied Nursing Research. Elsevier, V.39 pp. 130-140.

Demir Meryem r, (2014) “işsveren Markası ve İşveren Markasının Çalışan Memnuniyeti Üzerindeki Etkileri”Bahçeşehir Üniversitesi Yüksek Lisans Tezi.

Ergenç Alev, (1974) “i̧şe Bağlılığın Neden ve Sonuçları”Amme İdaresi Dergisi C.16 S.4 pp.9.

Eryılmaz Ali, Doğan Tayfun (2012) "iş Yaşamında Öznel lyi Oluş: Utrecht Işe Bağlılık Ölçeğinin Psikometrik Niteliklerinin incelenmesi", pp. 49-55.

Gül Hasan Erol Mikail, (2015) “Muhasebe Meslek Mensuplarında İşe Bağlıık, Çalışma Ahlakı Ve Mesleki Etik Davranış Iliş̧kilerinin Değerlendirilmesi" Çanakkale Onsekizmart Üniversitesi Doktora Tezi.

Hoş Canan, Oksay Aygen, (2015) "Hemşirelerde Örgütsel Bağlılık Ile işs Tatmini ilişkisi/ the Relationship Between Organizational Commitment and Job Satisfaction in Nurses", Süleyman Demirel Üniversitesi İktisadi ve İdari Bilimler Fakültesi Dergisi C.20, S.4 pp. 1-24.

Irmak Sezgin, Kuruüzüm Ayşe, Çetin Emre İpekçi, (2010) "İşe Bağlılığı Etkileyen Faktörler: Imalat ve Hizmet Sektörlerinde Karşılaştırmalı Bir Analiz", Türk Dünyası Sosyal Bilimler Dergisi S.53 pp. 183-198.

Kök Sabahat Bayrak, (2006) "Iş̧ Tatmini ve Örgütsel Bağlılığı Incelenmesine Yönelik Bir Araştırma”, Atatürk Üniversitesi İktisadi ve İdari Bilimler Dergisi, C.20, S.1.

Kanten Selahattin, Ömer Sadullah, (2012) "An Empirical Research on Relationship Quality of Work Life and Work Engagement", Procedia - Social and Behavioral Sciences, Elsevier B., V.62, pp. 360-366.

Koç Hakan, (2009) “Örgütsel Bağlıık ve Sadakat ilişkisi”, Elektronik Sosyal Bilimler Dergisi, C.8, S.28

Kara Melike Nur, (2013) "işsveren Markası ile Örgütsel Bağlıık Arasındaki ilişki" Uludağ Üniversitesi Sosyal Bilimler Enstitüsü Yüksek Lisans Tezi

Kartal Hakan, (2015) "Örgütsel Bağlıığı Etkileyen Etmenler ve Örgütsel Bağlıığın, İşe Bağlılık ve Ayrılma İsteği Gibi Kavramlarla Olan iliş̧kilerinin Uygulamalı Analizi" İstanbul Teknik Üniversitesi Yüksek Lisans Tezi

Kesoğlu ilay, (2017) “Örgütsel Bağııık ve Işsveren Markası Arasındaki ilişki ve Bir Araştırma” İstanbul Ticaret Üniversitesi Yüksek Lisans Tezi

Lievens Filip, (2007), "Employer Branding in The Belgian Army: The Importance of Instrumental and Symbolic Beliefs For Potantial Applicant and Military Employees" Human Resource Management, V. 46, N:1, SS:51-69

Negiz Nilüfer, Aygen Oksay, Akman Elvettin, (2011) "işse Bağlııı ve Işsten Tatmin Açısından Cinsiyet ve Sektörel Farklıık" Süleyman Demirel Üniversitesi Sosyal Bilimler Enstitüsü Dergisi C.2,S.14

Oğuz Nihan, (2012) "İşveren Markası ve Kabiliyeti Cezbetme Üzerine Etkisi" Ege Üniversitesi Yüksek Lisans Tezi

Öksüz Burcu, (2012) "Işletmelerde Örgütsel Çekiciliğin Arttırılmasında İşveren Markalaşması ve Insan Kaynaklarına Yansıması" Ege Üniversitesi Doktora Tezi

Özoral İrem Ela, (2013) "İşyerinde Eğlencenin İşe Bağlıık Üzerindeki Etkisi" Bahçeşehir Üniversitesi Yüksek Lisans Tezi.

Özdevecioğlu Mahmut, Aktaş Aylin (2007) "Kariyer Bağlıı̆̆ı, Mesleki Bağlılık Ve Örgütsel Bağıılığın Yaşam Tatmini Üzerindeki Etkisi: Iş̧-Aile Çatışmasının Rolü", Erciyes Üniversitesi İktisadi ve İdari Bilimler Fakültesi Dergisi, S.28, ss. 1-20. 
Pektaş Cem (2002) "Toplam Kalite Uygulamaları ve Demografik Değişkenlerin iş̧ Tatmini Boyutları ve Örgütsel Bağlılık Arasındaki Illişkiyi Farklılaştırması" Marmara Üniversitesi Yüksek Lisans Tezi

Porter Lyman.W., Steers Richard, Mowday Richard T., Paul V. Boulian (1974). "Organizational Commitment, Job Satisfaction, and Turnover Among Psychiatric Technicians", Journal of Applied Psychology, V.59, N.5.

Sabuncuoğlu Zeyyat, (2009) "Insan Kaynakları Yönetimi: Uygulamalı Örnekleriyle", 4. Basım, Furkan Ofset, Bursa

Sağır Mehmet, (2016) "İ̧̧veren Markası Algısı: Insan Kaynakları Faaliyetleri, Çalışma Ortamı Ve Tazminat-Kazanç Boyutları Ile Turizm Fakültelerinde Bir Uygulama". , C.8, S.14 pp. 416-439.

Schaufeli Wilmar B., (2018) "Work engagement in Europe", Organizational Dynamics, V.47, N.2.

Sharma Aarti, Goel Alok, Santoshi Sengupta, (2017) "How does Work Engagement vary with Employee Demography?: - Revelations from the Indian IT industry", Procedia Computer Science. Elsevier B. V.122, pp. 146-153.

Fatini Hanim Binti Mohamed Taufek,Zulhafiza BintiZulkifle, Mohamed Zulfadhli Bin Mohd Sharif (2016) "Sustainability in Employment: Reward System and Work Engagement", Procedia Economics and Finance. Elsevier B.V.35, pp. 699-704.

Terlemez Ayşe Gül, (2012) "İşveren Markasının, Işse Adanmışlık Ve Işsten Ayrılma Niyeti ile ilişsisinde Örgütsel Çekiciliğin Rolü" Genel Kurmay Başkanlığı Harp Akademileri Komutanlığı Stratejik Araştırmalar Enstitüsü Yüksek Lisans Tezi

Uyguç Nermin, Çımrın dilek, (2004) "Dokuz Eylül Üniversitesi Araştırma ve Uygulama Hastanesi Merkez Laboratuvarı Çalışanlarının Örgüte Bağlılı̆ını ve Işsten Ayrılma Niyetlerini Etkileyen Faktörler", D.E.Ü.i.i.i.B.F.Dergisi, C.19, S.1, pp. 91-99.

Yarar Burcu, (2016) "The Relationship between Personal Values, Calling and Work Engagement", Marmara Üniversitesi Sosyal Bilimler Enstitüsü İşletme Anabilim Dalı Örgütsel Davranış Bilim Dalı Yüksek Lisans Tezi pp. 26-28.

Vardarlıer Pelin, (2017) "İşveren Markası ve Yetenekli Çalışan Etkileşimi", İşletme Araştırmaları Dergisi, C.9,S.4. 
Eskişehir Osmangazi Üniversitesi iiBF Dergisi

\section{Extended Summary}

\section{Effect on the Employment of Employer's Brand: An Application for White Goods Industrial Employees}

In today's business world companies are aiming to reach out to business outcomes that can benefit the marketplace by holding qualified and distinguishing talents and keeping their employees, increasing their loyalty to the company. In this context, business world companies offer different activities and practices to their employees in various subjects such as wages and benefits, performance system, training, working conditions and environment, communication in order to keep their current employees. These activities and practices increase the loyalty of the employees to the organization and also indirectly achieve commitment to work. As it is known, it is possible to talk about the commitment of employees who have achieved commitment to work. In addition, business world companies measure employee loyalty from time to time. Commitment to work in the literature (Garber, 2007; Çakır, 2001; Carmeli, et al., 2004; Kuruüzüm, et al., 2010; Eryılmaz, Doğan 2012; Taufek, et al. 2015; Bayrak, 2016; Simone, et al., 2017; Kartal, there are many studies on 2017; Schaufeli, 2017; Sharma, 2017) and employer brand (Oğuz, 2012; Kara, 2013; Bay-rak, 2016; Dönmez, 2016; Aras, 2016). Studies have been conducted on both subjects separately and findings regarding the importance of these concepts for businesses and employees are included in the literature. Although studies examining the relationship between Commitment to work and organizational commitment and studies examining the relationship between employer brand and organizational loyalty are found in the literature, no studies evaluating the relationship between the two and Commitment to work and employer brand were found. This shortcoming in the literature is the starting point of this study. The purpose of this research is to determine whether the practices that they intend to pursue to keep employees under the employer brand name and attract potential candidates that they have an effect on the existing employees' commitment to work. The data of this research were collected from 223 white collar employees of a white goods company operating in the Eskişehir Organized Industrial Zone by survey technique. Demographic distribution of the participants was determined according to their age, seniority, department, position and graduation. The significance level was taken as $5 \%$ in all statistical analysis and SPSS 20.0 package program was used. In the research, variables were summarized by doing Explanatory Factor Analysis (EFA) separately for Commitment to work and employer brand. As a result of the Explanatory Factor Analysis (EFA) applied to the obtained data, employees' commitment scale 3 main factors are ("Identification of person with work", "Opinions about manager", "Work purpose and meaningfulness") employer brand scale 5 main factors are ("Organizational commitment", "Performance, career opportunities and rewards / appreciation", "Communication in terms of employees", "Working conditions and environment", "Eligible trainings"), The statistical comparison between the factors of commitment to work and employer branding differed according to the demographic variables of the employees. Among the factors in the employees' commitment scale, the "Identification of the person with the work done" factor was $24.65 \%$ of the employees' commitment scale, the "opinions about the manager" factor was $22.27 \%$ of the employees' commitment scale, and the "Work purpose and meaningfulness" factor was explaining 12,22 \% of the employees' commitment. The "Organizational Commitment" factor, one of the factors in the employer brand scale includes $19.36 \%$ of the employer brand scale, "Performance, career opportunities and rewarding / appreciation" factor, $17.79 \%$ of the employer brand scale, "Communication in terms of employees" factor $11.33 \%$, "Working conditions and environment" explain $11.27 \%$ of the employer brand scale, "Eligible trainings" explain $5.69 \%$ of the employer brand scale. As a result of the regression made to determine the effect of employer brand applications on employees' commitment to work; it has emerged that the employer's branding practices have a significant positive effect on their employees' commitment to work. Employer brand perception explains $48.7 \%$ of the change in employee commitment to work. As employees' satisfaction with employer brand practices increases, their commitment to work also increases. 1 point positive perceptions of employees towards employer brand practices cause an increase of 0,699 points in their commitment to work. With the thought that the factors of employer brand scale obtained with EFA may have separate effects, the effects of these factors on commitment to work were examined with multiple linear regression analysis by taking each independent factor of employer brand scale as an independent variable. There is a strong positive relationship between employer brand factors and commitment to work. Employer brand factors explain commitment to work by $49.8 \%$. Organizational commitment is the factor that has the most impact among employer brand factors that have a statistically significant effect on commitment to work. A 1 point positive perception increase in employee loyalty to their organizations results in an increase of 0,206 point in their commitment to work. As a result, especially the high level of organizational commitment reflects positively on commitment to work and has more impact than other factors. Therefore, businesses that want to increase their commitment to work should attach importance to creating an employer brand with high organizational commitment. 